\title{
Study of The Soft Skills Development in The Framework Of The Activities Of Student Communities
}

\section{Estudio del Desarrollo de Habilidades Blandas en el Marco de las Actividades de las Comunidades Estudiantiles}

\author{
Vera Viktorovna Kolchina \\ Candidate of Pedagogical Sciences, Assistant Professor, Ural State University of Economics, \\ Yekaterinburg, Russia \\ https://orcid.org/0000-0003-1721-1472 \\ Dmitry Vladimirovich Lukashenko \\ Doctor of Psychological Sciences, Associate Professor, Leading Researcher, Research \\ Institute of the Federal Penitentiary Service of the Russian Federation, Moscow, Russia \\ https://orcid.org/0000-0002-0045-6062
}

\section{Marina Georgiyevna Sergeeva}

Doctor of Pedagogical Sciences, Assistant Professor, Chief Researcher; Federal State Institution

"Research Institute of the Federal Penitentiary Service of Russia, Moscow, Russia

https://orcid.org/0000-0001-8365-6088

Regina Dmitrievna Cherepakhina

Assistent of Department of Foreign Languages Academy of Engineering, Peoples' Friendship University of Russia (RUDN University), Moscow, Rusia https://orcid.org/0000-0003-3149-3584

Received 09-08-20 Revised 10-10-20

Accepted 12-12-20 On line 03-18-21

*Correspondencia

Email: vera.kolchina.1975@mail.ru 


\section{Summary}

The article presents the results of a study of the Soft Skills development in the activities of student societies. The purpose of the article is the theoretical and empirical study of the Soft Skills development in the activities of student societies. The research methodology and its algorithm were selected due to the purpose of the study. To solve the research questions posed, we compiled a list of student societies of the Mytischi Branch (MB) of the Bauman Moscow State Technical University. It included 87 student societies, which were classified according to the type of their activity. The hypothesis of the research is that a close connection between student societies stimulates members of one society to be interested in the activities of associate societies, thereby acquiring new skills within the framework of this activity, among which there are so-called Soft Skills. Student societies can form both general, characteristic of all student organizations, and specific skills, characteristic of certain types of activity. In the course of the research work, all possible student societies were identified and classified. Next, we built a network map of the interaction among student societies. Also, using a targeted sample, 9 student societies were selected, representing different fields of activity. The leaders of these societies were interviewed using a semi-formalized interview method. The statutory documents on the activities of the societies under consideration were analyzed using the traditional method of document analysis.

Keywords: Soft Skills, Hard Skills, Student Societies, Professional Development, Professiogram.

\section{Resumen}

El artículo presenta los resultados de un estudio del desarrollo de Soft Skills en las actividades de las sociedades estudiantiles. El propósito del artículo es el estudio teórico y empírico del desarrollo de Soft Skills en las actividades de las sociedades estudiantiles. La metodología de investigación y su algoritmo fueron seleccionados en función del propósito del estudio. Para resolver las preguntas de investigación planteadas, compilamos una lista de sociedades de estudiantes de la Rama Mytischi (MB) de la Universidad Técnica Estatal de Moscú Bauman. Se incluyeron 87 sociedades de estudiantes, que se clasificaron según el tipo de actividad. La hipótesis de la investigación es que una estrecha conexión entre sociedades estudiantiles estimula a los miembros de una sociedad a interesarse por las actividades de las sociedades asociadas, adquiriendo así nuevas habilidades en el marco de esta actividad, entre las que se encuentran las denominadas Soft Skills. Las sociedades de estudiantes pueden formar tanto habilidades generales, características de todas las organizaciones de estudiantes, como habilidades específicas, características de ciertos tipos de actividad. En el transcurso del trabajo de investigación, se identificaron y clasificaron todas las posibles sociedades de estudiantes. A continuación, construimos un mapa en red de la interacción entre sociedades estudiantiles. Además, utilizando una muestra específica, se seleccionaron 9 sociedades de estudiantes, que representan diferentes campos de actividad. Los líderes de estas sociedades fueron entrevistados utilizando un método de entrevista semi-formalizado. Los documentos estatutarios sobre las actividades de las sociedades consideradas se analizaron utilizando el método tradicional de análisis de documentos.

Palabras clave: Soft Skills, Hard Skills, Sociedades de estudiantes, Desarrollo profesional, Profesiograma.

\section{Introducción}

From the standpoint of the achievements of modern psychological science, in particular developmental psychology and educational psychology, such a concept as Soft Skills, which are a combination of qualities, abilities and personality traits, that contribute to professional development and an increase in personal effectiveness, comes into use. In conjunction with 
Hard (professional) Skills, Soft Skills allow educators to describe almost the entire spectrum of the professiogram, or professionally significant qualities in any area of activity. Within the framework of this article, the problem of the Soft Skills development as a component of the social abilities of student societies members is considered. Attention is drawn to the fact that the parameters under consideration could be effectively developed only within the framework of activities related to its implementation. The process of its development within the framework of the activities of student societies is studied (Vasbieva, 2018; Blinova et al., 2018).

\section{Literature review}

Nowadays student societies occupy a significant place in the higher education system. Student associations are viewed as centers of creative, intellectual, personal development of students. As part of their activities, educational functions, functions of forming an active civic position, forming cultural values, personal and professional competencies are implemented. Research materials that focus on student life suggest that undergraduate students tend to assess the significance of student life experiences in the broadest sense. Student social life is an important element of the valuable experience that studying at the university is for young people (Klyukovskaya, 2007).

Studying outside the walls of the classroom is often in practice more crucial than the lessons within these walls. In addition to organizing student life, the university offers options for a highly structured experience that are more or less associated with the curricula. This, in particular, could be education abroad and / or real work and practice (Bogdan, 2017).

For this research the works of Talcott Parsons, American sociologist, best known for his social action theory and structural functionalism, as well as David Durkheim, Max Weber, V. Pareto, F. Znanetsky, the representatives of the theory of activity approach, were taken as theoretical and methodological foundations. We also analyzed the theoretical works of the researchers in the field of higher education M. Barber, K. Donnelly, J. Salmi, O. Chulanova, V. Demin and E. Sukhanova devoted to the subject of this study.

It is important to note that the student society is a tool for bringing the personal interests of undergraduate and postgraduate students and teachers into contact. Each member of the student society gets a new life experience. The special conditions created by the university enable the development of student societies, which expand and exaggerate the civic, professional and personal characteristics of students (Demin and Sukhanova, 2015; Gorev et al., 2018; Bírová et al., 2018; Chulanova, Ivonina, 2017). Students enter these communities for personal reasons, interests, an active life position, as well as the desire to make a certain contribution to the development of society, science, culture, and so on.

The basis of the activity of student societies is the implementation of various projects, targeted programs, aimed at solving specific, important for students and public tasks (group of problems) in the context of their study of a main or additional educational program (Lukyanov, 2013; Sharonova et al., 2018).

We consider student societies through the prism of activity approach, therefore, student organizations should be studied from the point of view of the their leading action lines and the development of the necessary competencies, in particular, Soft Skills. In turn, these skills are the foundations for the development of other parameters related to the professional and personal development of students.

\section{Proposed methodology}

The object of this research is student societies of the Mytischi Branch of Bauman Moscow State Technical University, and the subject is Soft Skills formed within these societies. To solve the research questions posed, we compiled a list of student societies of the Mytischi Branch of 
Bauman Moscow State Technical University, which included 87 student societies. We classified them by the type of activity. A network map of student societies has been built, with the help of which it is possible to trace the direct and indirect (through the nodes of the network) relationships between student societies. Based on the analysis of statutory documents (regulations and charters), as well as informal interviews with managers and chairs, a list of Soft Skills formed within the framework of the activities of these societies was identified and classified (Volkova, Panchenko, 2018).

The revealed Soft Skills can be divided into general and specific: skills that are formed in most student societies and skills that are formed in individual student societies, depending on their type of activity. It should be noted that all analyzed statutory documents declare the formation of Soft Skills as the important tasks of their activities.

All of the interviewed leaders of student societies who have relations with other communities are confident that the interaction between the communities of the Mytischi Branch of Bauman Moscow State Technical University, of course, contributes to the development of various skills among their members.

Table (1): Algorithm of actions in the course of the experiment

\begin{tabular}{c}
\hline Algorithm of actions \\
\hline 1) analysis of available student societies and their mapping \\
\hline 2) student societies documents analysis \\
\hline 3) informal interview of student societies leaders \\
\hline
\end{tabular}

\section{Result Analysis}

This research was devoted to the study of the Soft Skills development within student societies, as well as the identification of the list of Soft Skills that are formed in student societies, implementing different areas of activity. The main research questions were as follows:

Is the Soft Skills development a targeted task of the university student societies?

What skills could be developed in different types of student societies? (Dolzhich, Dmitrichenkova, 2018).

The purpose of our research was to determine the Soft Skills that are formed in student societies implementing different areas of activity. The hypothesis of the study was defined as follows: A close connection between student societies stimulates members of one community to be interested in the activities of associate societies, thereby acquiring new skills within the framework of this activity, among which there are so-called Soft Skills. Student societies are capable of developing both general skills, characteristic of all student organizations, and specific ones, characteristic of certain types of communities.

In the experimental process, all possible student societies were identified and classified. Next, a network map of student societies interaction was built. Also, using a targeted sample, 9 student societies were selected, representing different fields of activity. The leaders of these societies were interviewed using the semi-formalized interview method. The leaders also presented statutory documents on the activities of their organizations, which were analyzed using the traditional method of document analysis.

Based on the analysis performed, we distinguished the following skills which could be classifies as the Soft Skills:

\section{Communication skills:}

- ability to work in a team, group

- skills of conflict resolution 
- skills of intercultural communication

- increasing the level of tolerance

- public speaking skills

- development of foreign language skills, increase in vocabulary

- analytical / research skills:

- skills of project activities

- development of free thinking, analytical, reflective skills

- skills of independent research projects

- skills of creating, developing and implementing innovative humanitarian projects

- development of innovative thinking

- flexibility / adaptability / thinking:

- stress resistance

- mobility

- ability to act in critical situations

- intellectual growth

- development of scientific and creative potential

- development of the speed of thinking

- critical thinking

\section{Organizational skills:}

- solving social problems

- organization of events

- skills of self-organization

- time management

- punctuality

- management skills

- skills in the development and implementation of career guidance and information and leisure forms of work

\section{Professional skills (according to the specifics of the activity):}

- professional skills of photo and video shooting, journalism

- technical skills

- working with children and parents 
- professional teaching skills

- raising the philosophical culture

- language skills

- growth of sports achievements

- promotion of healthy lifestyle

- business skills

- creation of information materials

- digital skills

- administrative skills

Skills for the self-development:

- broadening of the worldviews

- development of personal qualities (responsiveness, benevolence, kindness, responsibility)

- self-realization and self-government

- self-development

- development of responsibility

Skills of social activity:

- enhancing the culture

- humanistic and patriotic education

- citizenship skills

- social and cultural adaptability

- social communication skills

- formation of civic culture and active civic position

- development of social maturity.

Our classification of Soft and Hard (professional) Skills made it possible to analyze their development in different types of student societies.

Table 2 below provides a summary of the information obtained.

Table (2): Soft Skills groups development in different types of student societies

\begin{tabular}{|c|c|c|c|c|c|c|c|}
\hline \multirow[b]{2}{*}{$\begin{array}{l}\text { Types of } \\
\text { student } \\
\text { societies } \\
\text { (by } \\
\text { activity) }\end{array}$} & \multicolumn{7}{|c|}{ Soft Skills } \\
\hline & $\begin{array}{c}\text { Communi } \\
\text {-cative } \\
\text { skills }\end{array}$ & $\begin{array}{c}\text { Analytica } \\
\text { l / } \\
\text { research } \\
\text { skills }\end{array}$ & $\begin{array}{l}\text { Flexibility/ } \\
\text { Adaptabilit } \\
\text { y / thinking }\end{array}$ & $\begin{array}{c}\text { Leadershi } \\
\text { p skills }\end{array}$ & $\begin{array}{l}\text { Professiona } \\
\text { l skills } \\
\text { (according } \\
\text { to the } \\
\text { specifics of } \\
\text { the }\end{array}$ & $\begin{array}{c}\text { Persona } \\
1 \\
\text { develop } \\
\text {-ment } \\
\text { skills }\end{array}$ & $\begin{array}{c}\text { Social } \\
\text { Activit } \\
\text { y Skills }\end{array}$ \\
\hline
\end{tabular}




\begin{tabular}{|c|c|c|c|c|c|c|c|}
\hline Hobby & + & - & - & + & + & + & + \\
\hline Professional & + & - & - & + & + & + & + \\
\hline Student & + & - & + & + & + & + & + \\
\hline Internationa & + & - & + & + & + & + & + \\
\hline Volunteerin & + & - & + & + & + & + & + \\
\hline Sporting & + & - & + & + & + & + & - \\
\hline Camp & + & + & + & + & + & + & + \\
\hline $\begin{array}{c}\text { Career } \\
\text { guidance }\end{array}$ & + & + & - & - & + & + & - \\
\hline $\begin{array}{c}\text { Short-term } \\
\text { volunteer } \\
\text { projects }\end{array}$ & + & + & - & - & + & + & + \\
\hline Faculty & + & + & + & - & + & + & - \\
\hline Social clubs & + & + & + & - & + & + & - \\
\hline Scientific & - & + & + & + & + & - & - \\
\hline
\end{tabular}

Thus, the data obtained allowed us to determine the general skills characteristic of more than half (at least 6 out of 9) of the types of student societies participating in the research. These are organizational skills, communication skills, personal development skills, professional skills (according to the specifics of the activity). Specific skills emerging in some student societies are analytical / research skills, flexibility / adaptability / thinking, and social activity skills.

The obtained results of empirical research indicate the presence of tasks for the development of Soft Skills, declared in the statutory documents. It is worth noting that student societies leaders point to Soft and Hard (professional) Skills that are emerging within their societies. All of them could be divided into general and specific: skills that are formed in most societies and skills that are formed depending on the type of activity of student societies. General skills include organizational skills, communication skills, the ability to navigate in stressful situations. These skills were mentioned most often. Specific skills include working with children, knowledge of foreign languages, public speaking, practicing sports skills, etc.

\section{Conclusion}

Based on the results obtained, the following conclusions were drawn:

1. Student societies are classified by type of activity into volunteer, scientific, interest clubs (cultural organizations), trade unions, sports, social groups, career guidance, international, faculty societies.

2. Documentary analysis of statutory documents showed that the formation of certain types of Soft Skills is an explicit function (task) of student societies. These skills could be divided into two groups: general and specific skills. General skills are common to more than half of the student societies participating in the research. These are organizational skills, communication skills, personal development skills, professional skills (according to the specifics of the activity). Specific skills emerging in some student societies are analytical / research skills, flexibility / adaptability / thinking, and social activity skills.

3. Different types of student societies develop different types of Soft Skills. It was revealed that in all types of student societies, professional skills are also formed, moreover, related to both Soft Skills and Hard Skills.

4. The potential for interaction between student societies can be used to develop new Soft Skills in students.

\section{Referencias}

Barber, M., Donnelly, K., Rizvi, S. (2013) An avalanche is coming. Higher education and the revolution ahead. Leningrad: The Institute for Public Policy Research. Education Issues. 
Bírová, J., Kružlík P., Kalimullin, A., Sokolova, N., Haroun, Z., Králik, R., Vasbieva, D. (2018). Mathematical and Statistical Bibliometric Indicators for Scholars in the Field of Romance Languages and Linguistics. EURASIA: Journal of Mathematics, Science and Technology Education, 14(12).

Blinova, S., Dugina, T., Zabolotskikh, A. (2018). Teaching mixed nationality groups (on the example of students from the Northern Caucasus region). INTED2018: Proceedings of the 12th International Technology, Education and Development Conference, Valencia, Spain.

Bogdan, E.S. (2017). Development of soft skills among engineering students as an important factor in their competitiveness. Actual problems of the humanities and natural sciences, 2-4: 17-20.

Chulanova, O.L., Ivonina, A.I. (2017). Formation of soft-skills (soft competencies): approaches to the integration of Russian and foreign experience, classification, operationalization. Human Resources and Intellectual Resources Management in Russia, 1 (28): 53-58.

Demin, V.V., Sukhanova, E.A. (2015) Network interaction of the classical research university and the system of general education: experience and prospects. Informatics and education, 6(266): 3-5.

Dolzhich, E., Dmitrichenkova, S. (2018). Computer science terminology (a case study of the Spanish language). INTED2018: Proceedings of the 12th International Technology, Education and Development Conference, Valencia, Spain.

Gorev, P., Telegina, N., Karavanova, L., Feshina, S. (2018). Puzzles as a didactic tool for development of mathematical abilities of junior schoolchildren in basic and additional mathematical education. EURASIA: Journal of Mathematics, Science and Technology Education, 14 (10): 178-185.

Klyukovskaya, I. (2007). Are functional skills not enough? Retrieved from: http://www.management.com.ua/notes/soft_skills.html

Lukyanov, F. (2013). Hard and soft skills. Retrieved from: https://delovoymir.biz/2013/02/19/tverdye-i-myagkie-navyki.html

Sharonova, S., Trubnikova, N., Sokolova, N. (2018). Interpreting religious symbols as basic component of social value formation. European Journal of Science and Theology, 14(3): 117-129.

Vasbieva, D.G., Sokolova, N.L., Masalimova, A.R., Shinkaruk, V.M., Kiva-Khamzina, Y.L. (2018). Exploring the EFL teacher's role in a smart learning environment - a review study. XLinguae, 11(2): 265-274.

Volkova, Y., Panchenko, N. (2018). Discourse variation of the concepts of destructive emotions. Vestnik Rossiiskogo Universiteta Druzhby Narodov: Russian journal of linguistics, 22(1): 175-194. 